\title{
Temperature induced variation in gene expression of thyroid hormone receptors and deiodinases of European eel (Anguilla anguilla) larvae
}

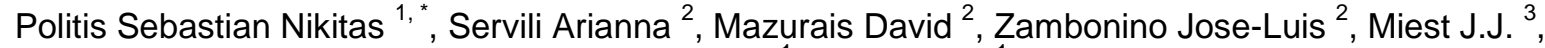 \\ Tomkiewicz J. ${ }^{1}$, Butts I.A.E. ${ }^{1}$
}

${ }^{1}$ Technical University of Denmark, National Institute of Aquatic Resources, Lyngby, Denmark

2 Ifremer, Marine Environmental Science Laboratory UMR 6539, Plouzané, France

${ }^{3}$ Helmholtz Centre for Ocean Research, Kiel, Germany

* Corresponding author : Sebastian Nikitas Politis, email address : snpo@aqua.dtu.dk

\begin{abstract}
:
Thyroid hormones (THs) are key regulators of growth, development, and metabolism in vertebrates and influence early life development of fish. TH is produced in the thyroid gland (or thyroid follicles) mainly as T4 (thyroxine), which is metabolized to T3 (3,5,3'-triiodothyronine) and T2 (3,5-diiodothyronine) by deiodinase (DIO) enzymes in peripheral tissues. The action of these hormones is mostly exerted by binding to a specific nuclear thyroid hormone receptor (THR). In this study, we i) cloned and characterized thr sequences, ii) investigated the expression pattern of the different subtypes of thrs and dios, and iii) studied how temperature affects the expression of those genes in artificially produced early life history stages of European eel (Anguilla anguilla), reared in different thermal regimes $(16,18,20$ and $22^{\circ} \mathrm{C}$ ) from hatch until first-feeding. We identified 2 subtypes of thr (thra and thr $\beta$ ) with 2 isoforms each (thraA, thraB, thr $\beta A$, thr $\beta B$ ) and 3 subtypes of deiodinases (dio1, dio2, dio3). All thr genes identified showed high similarity to the closely related Japanese eel (Anguilla japonica). We found that all genes investigated in this study were affected by larval age (in real time or at specific developmental stages), temperature, and/or their interaction. More specifically, the warmer the temperature the earlier the expression response of a specific target gene. In real time, the expression profiles appeared very similar and only shifted with temperature. In developmental time, gene expression of all genes differed across selected developmental stages, such as at hatch, during teeth formation or at first-feeding. Thus, we demonstrate that the expression of thrs and dios show sensitivity to temperature and are involved in and during early life development of European eel.
\end{abstract}




\section{Highlights}

- European eel larvae were produced via assisted reproduction in captivity. Thyroid hormone pathway (thraA-B, thr $\beta A-B$ and dio1-3) related genes identified. European eel thyroid hormone receptor sequences were cloned and characterized. Temperature, larval age and/or their interaction affected gene expression. Vertebrate thyroid hormone receptor sequences were phylogenetically analyzed.

Keywords : Deiodinases, Thyroid hormone receptors, Fish, Larvae, Early life history 


\section{Introduction}

The European eel (Anguilla anguilla) has been subjected to extensive scientific inquiry due to its enigmatic natural ecology (Van Ginneken and Maes, 2005; Miller et al., 2015; Righton et al., 2016), the critically endangered status of the population (Jacoby and Gollock, 2014), and the ongoing natural and anthropogenic pressures on the already historically low stock (Friedland et al., 2007; Bonhommeau et al., 2008; Geeraerts and Belpaire, 2010; ICES, 2015). As such, researchers are now employing technological means to circumvent the European eel decline and are striving to establish a sustainable aquaculture. Unfortunately, the aquaculture industry for European eel has been drastically reduced (ICES, 2015) due to the fact that it is capture-based, relying on wild-caught offspring (juvenile glass eels), which are unsustainably farmed until marketable size. The earliest life stages of European eel have not been encountered in nature, thus research needs to focus on laboratory studies to overcome current bottlenecks and gain knowledge about the species physiology and ecology. With recent advances in assisted reproduction (Butts et al., 2014; Müller et al., 2016; da Silva et al., 2016) and larval culture of European eel (Politis et al., 2014a; Sørensen et al., 2016; Butts et al., 2016) this is now possible and warrants further investigation. In addition, the European eel genome has recently been sequenced (Henkel et al., 2012), which offers new and emerging perspectives for fundamental molecular studies in eel biology (Rozenfeld et al., 2016).

In order to close the life cycle in captivity, similar bottlenecks needed to be overcome regarding the closely related Japanese eel (Anguilla japonica), which was accomplished in recent years (Masuda et al., 2012; Tanaka, 2015). Extensive efforts have been devoted to reach breakthrough achievements, forming the baseline knowledge for eel research (Tanaka et al., 2001, 2003). Subsequently, several studies have focused on assessing the extrinsic (environmental) and intrinsic (genetic) requirements and preferences of all life stages in order to identify the most 
optimal conditions for rearing early life history (ELH) stages of this species (Yamano et al., 2007; Ahn et al., 2012; Hsu et al., 2015). However, still there seems to be large variation and differences in larval growth of artificially and naturally reproducing eels (Miller, 2009). Environmental factors such as temperature have been shown to drastically influence larval morphology and survival (Okamura et al., 2007; Ahn et al., 2012). Moreover, it was shown that the thyroid hormone (TH) pathway may control the early life development of Japanese eels, similar to Japanese conger eels (Conger myriaster) through thyroid hormone receptors (THR) (Kawakami et al., 2003; Kawakami et al., 2013). Thus, TH treatment has been applied to enable synchronized metamorphosis leading to a lower developmental variability (Yamano et al., 2007).

Generally, THs are key regulators of growth, development, and metabolism in vertebrates (Power et al., 2001, Warner and Mittag, 2012, Tata, 2006). THs are produced in the thyroid gland (or thyroid follicles) mainly as T4 (thyroxine), which is metabolized to T3 (3,5,3'-triiodothyronine) and T2 (3,5-diiodothyronine) by deiodinase enzymes (DIO1-3) in peripheral tissues (Köhrle, 2000). The action of THs are mostly exerted by binding to specific nuclear THRs, although a non-genomic pathway has been shown to mediate TH functions through cellular signal transduction systems and cell surface receptors (Davis et al., 2008). THRs belong to the subfamily I of nuclear hormone receptors and share a modular structure composed of a $\mathrm{N}$-terminal region (termed $\mathrm{A} / \mathrm{B}$ domain), a conserved DNA binding domain (DBD or C region), a less conserved hinge region (D) followed by the ligand binding domain (LBD or $\mathrm{E}$ domain), and the $\mathrm{C}$-terminal region (F region). In mammals, two genes (thr $\alpha$ and $t h r \beta$ ) generally encode THR $\alpha$ and THR $\beta$ (Lazar et al., 1993), whereas several genes encoding THR $\alpha$ and THR $\beta$ can be found in fish, due to teleost genome duplication events (Nelson and Habibi, 2009). For instance, two thra genes have been described in zebrafish, Danio rerio (Takayama et al., 2008) and other fish species (Bertrand et al., 2007), while two thr $\beta$ have been reported in Japanese conger eel (Kawakami et al., 2003). 
Increasing evidence suggests that THs have important roles during early life development and metamorphosis in fish (Marchand et al., 2004, Walpita et al., 2007, Infante et al., 2008, Campinho et al., 2010). The Japanese conger eel (Kawakami et al., 2003) and the Japanese eel (Kawakami et al., 2013) were previously chosen as model species to investigate the TH role on development and metamorphosis of Anguilliformes. An investigation of two isoforms of thro (thraA and thraB) and two isoforms of $\operatorname{thr} \beta$ ( $\operatorname{thr} \beta A$ and $\operatorname{thr} \beta B$ ) showed differentially regulated gene expression for all isoforms during development and metamorphosis in Japanese eel (Kawakami et al., 2013). Thyroid hormones induce differential transactivation activity of the different $t h r$ isoforms, and interestingly, elevated gene expression was observed between hatching and the transition to exogenous feeding (Kawakami et al., 2013). Thus, it is of importance to further elucidate the thr expression profiles during this sensitive period of anguillid ELH, but especially during the still mysterious ELH of European eel.

The objectives of this study were to i) clone and characterize thr sequences, ii) follow the expression pattern of thrs and dios, and iii) investigate how temperature affects the expression of those genes in artificially produced ELH stages of European eel, reared in different thermal regimes from hatch until first-feeding.

\section{Materials and Methods}

All fish were handled in accordance with the European Union regulations concerning the protection of experimental animals (Dir 86/609/EEC). Experimental protocols were approved by the Animal Experiments Inspectorate (AEI), Danish Ministry of Food, Agriculture and Fisheries (permit number: 2012-15-2934-00458). Adult eels were anesthetized using ethyl paminobenzoate (benzocaine) before tagging and handling. Endogenously feeding larvae of European eel were 
anesthetized prior to handling and euthanized prior to sampling by using tricaine methanesulfonate (MS-222). All efforts were made to minimize animal handling and stress.

\subsection{Broodstock management and gamete production}

Female silver eels were wild-caught (lake Vandet, Jutland, Denmark), while male eels were farmed (Stensgård Eel Farm A/S). Prior to experimental maturation, the fish were transported to a DTU Aqua research facility (Lyksvad Fishfarm, Vamdrup, Denmark), and housed in 300 L tanks equipped with a recirculation system (Tomkiewicz, 2012). Eels were maintained under low intensity light ( 20 lux $), 12 \mathrm{~h}$ day/12 h night photoperiod, salinity of $\sim 36 \mathrm{ppt}$, and temperature of $20^{\circ} \mathrm{C}$. Acclimatization took place over 14 days and the eels were not fed during the entire experimental period. Furthermore, eels were anaesthetized (ethyl p-aminobenzoate, $20 \mathrm{mg} \mathrm{L}^{-1}$; Sigma-Aldrich, Missouri, USA) and tagged with a passive integrated transponder. To induce vitellogenesis females received weekly injections of salmon pituitary extract (Argent Chemical Laboratories, Washington, USA) at $18.75 \mathrm{mg} \mathrm{kg}^{-1}$ body weight (Kagawa et al., 2005; Tomkiewicz, 2012). To stimulate follicular maturation and induce ovulation, females received $17 \alpha, 20 ß-$ dihydroxy-4-pregnen-3-one (Sigma-Aldrich, Missouri, USA) at $2 \mathrm{mg} \mathrm{kg}^{-1}$ body weight (Ohta et al., 1996) and were strip-spawned after 12-14 h. Males received weekly injections of human chorionic gonadotropin (Sigma-Aldrich, Missouri, USA) at $150 \mathrm{IU} / \mathrm{fish}$ (Tomkiewicz, 2012). Prior to fertilization, an additional injection was given and milt was collected by strip-spawning $\sim 12 \mathrm{~h}$ after administration of hormone. Milt samples were pipetted into a P1 immobilizing medium (Peñaranda et al., 2010) and only males with sperm motility of category IV (75-90\%) were used for fertilization, within 4 h of collection (Butts et al., 2014). Eggs from each female were strip-spawned and fertilized separately by different sperm pools to create individual parental crosses. 
Subsequently, $0.2 \mu \mathrm{m}$ filtered UV sterilized North Sea seawater was added for a gamete contact time of $5 \mathrm{~min}$. Seawater was adjusted to $20^{\circ} \mathrm{C}\left( \pm 0.1^{\circ} \mathrm{C}\right)$ and $36( \pm 0.1)$ ppt using Red Sea Salt (Red Sea Europe, Verneuil-sur-Avre, France). Only floating viable eggs/embryos were further used for experimentation.

\subsection{Experimental conditions and design}

During the spawning season, $25 \%$ of females successfully produced larvae after assisted reproduction treatments. Females represented here $(n=4)$ had a mean $( \pm$ SEM $)$ standard length and body weight of $65 \pm 4 \mathrm{~cm}$ and $486 \pm 90 \mathrm{~g}$, respectively, while males $(\mathrm{n}=11)$ had a mean $( \pm \operatorname{SEM})$ standard length and body weight of $40 \pm 3 \mathrm{~cm}$ and $135 \pm 25 \mathrm{~g}$, respectively. In this study, four individual parental crosses were used. Egg density for each parental combination was determined by counting $3 \times 0.1 \mathrm{~mL}$ subsamples from the floating layer. Within 30 min post fertilization, $\sim 500$ floating viable eggs/embryos per $100 \mathrm{~mL}$, with a mean size $( \pm \mathrm{SD}$ ) of $1.5 \pm 0.1 \mathrm{~mm}$ (at 2 hours post fertilization), were distributed in replicated $600 \mathrm{~mL}$ flasks $\left[182.5 \mathrm{~cm}^{2}\right.$ sterile tissue culture flasks with plug seal caps $\left(\mathrm{VWR}^{\circledR}\right)$ ]. Seawater was supplemented with rifampicin and ampicillin (each 50 $\mathrm{mg} \mathrm{L}^{-1}$, Sigma-Aldrich, Missouri, USA), which previously has been shown to increase survival in a controlled experimental environment (Sørensen et al., 2014). Embryos and larvae, from each parental cross, were reared in thermally controlled incubators (MIR-154 Incubator, Panasonic Europe B.V.) at five temperatures $\left(16,18,20,22\right.$, and $\left.24^{\circ} \mathrm{C} \pm 0.1^{\circ} \mathrm{C}\right)$. All experimental units were acclimatized to the appropriate temperature regime within $1 \mathrm{~h}$ and salinity was kept at $36 \pm 1 \mathrm{ppt}$. Temperature and salinity conditions were chosen to closely resemble the environmental conditions encountered at different depths of the assumed spawning areas in the Sargasso Sea (Castonguay and McCleave, 1987). Rearing of embryos and larvae took place in darkness, while handling and 
sampling was conducted under low intensity $\left(<2.2 \mu \mathrm{mol} \mathrm{m} \mathrm{m}^{-2}\right)$ light conditions (Politis et al., 2014a). At hatch and every second day post-hatch until the corresponding first-feeding stage (Fig. 1), 30 larvae from each parental cross $(\times 4)$, each temperature $\left(16,18,20\right.$ and $\left.22^{\circ} \mathrm{C}\right)$, and each replicate $(\times 2)$ were randomly sampled for later molecular analyses. Those endogenously feeding larvae were immediately euthanized using MS-222 (Sigma-Aldrich, Missouri, USA), rinsed with deionized water, preserved in a RNA Stabilization Reagent, and kept at $-20^{\circ} \mathrm{C}$ following the procedure suggested by the supplier (Qiagen, Hilden, Germany). For further details on experimental design, rearing conditions, as well as larval morphology and development see Politis et al. (2017).

\subsection{Data collection}

\subsubsection{Cloning and molecular characterization}

cDNA sequences for thrs were predicted from genomic DNA sequences originating from the European eel genome assembly (WGS Project: AZBK01), available in NCBI resources (Henkel et al., 2012). Briefly, blastn requests were performed from Japanese eel cDNA thr sequences on the European eel WGS database to identify genomic contigs, including thr genes. European eel thr cDNA sequences were then deduced from contigs using GENSCAN (http://genes.mit.edu/GENSCAN.html) software (Burge et al., 1997). The predicted transcript sequences for each thr gene were confirmed by sequencing cDNAs from European eel RNA amplification. Cloning was achieved using TOPO TA cloning kit (Invitrogen) with pCR ${ }^{\text {TMII- }}$ TOPO® vector, according to the manufacturer's instructions. Primers sequences were as follows:

thraA (F) 5'-GGGTCGCTGAGGAGACCT-3', thraA (R) 5'-GGTGCTCAGACGTCCTGGT-3', 


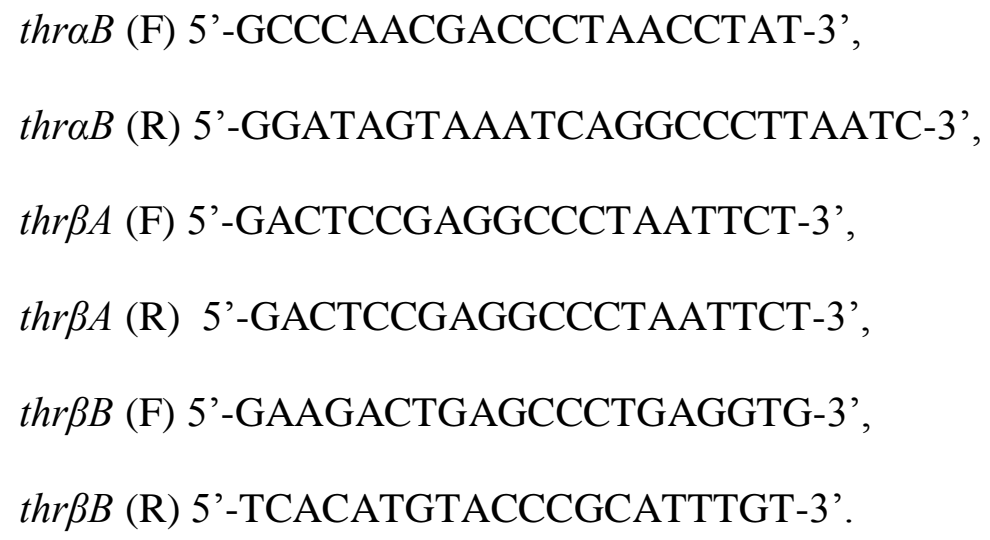

The cloned cDNA was sequenced with T7 and Sp6 primers by Beckman Coulter Genomics Inc (United Kindom). European eel thr cDNA sequences have been deposited to GenBank® with accession numbers found in Table 1.

\subsubsection{Phylogenetic analysis}

A phylogenetic tree was constructed using the Neighbor-Joining method (Saitou and Nei, 1987) with amino acid $t h r$ vertebrate sequences. The evolutionary distances were computed using the JTT matrix-based method (Jones et al., 1992) and are in the units of the number of amino acid substitutions per site. All positions containing gaps and missing data were eliminated. For the analysis, 1000 bootstrap replicates were carried out. Phylogenetic analysis was conducted in MEGA6 (Tamura et al., 2013). The GenBank accession numbers of the sequences used can be found in the Supplementary material.

\subsubsection{Gene expression}

For total RNA extraction, the larval pool ( $\sim 30$ larvae) of each replicate was homogenized in $800 \mu 1$ Tri-Reagent (Sigma-Aldrich, Missouri, USA). After obtaining the aqueous phase by 
incubation in $160 \mu$ l chloroform, RNA was extracted using the InviTrap ${ }^{\circledR}$ Spin tissue RNA MiniKit (STRATEC Biomedical AG, Berlin-Buch, Germany) following the manufacturer's instructions. RNA concentration and purity were determined by spectrophotometry $(260 / 280=2.12 \pm 0.16$, $230 / 260=2.16 \pm 0.16$ ), using Nanodrop ND-1000 (Peqlab, Germany). From the resulting total RNA, 680 ng were transcribed using the Quanta qScript cDNA Synthesis Kit (Promega, Germany), according to the manufacturer's instructions, including an additional gDNA wipe out step prior to reverse transcription [Quanta PerfeCta DNase I Kit (Promega, Germany)].

The expression levels of target genes (thyroid hormone receptors: thr $\alpha A$, thr $\alpha B$, thr $\beta A$, thr $\beta B$ and deiodinases: dio1, dio2, dio3) and reference genes (ef1 $\alpha, 18 s, 40 s)$ were determined by quantitative real-time PCR (qRT-PCR) using specific primers. The efl $\alpha, 18 s, 40 s$ genes were chosen as housekeeping genes since qBase+ software revealed that these mRNA levels were stable throughout analyzed samples $(\mathrm{M}<0.4)$; $\mathrm{M}$ gives the gene stability and $\mathrm{M}<0.5$ is typical for stably expressed reference genes (Hellemans et al., 2007). Using primer 3 software v 0.4.0 (http://frodo.wi.mit.edu/primer3/) primers were designed i) for thr $\alpha A$, thr $\alpha B$, thr $\beta A$ and $t h r \beta B$ based on cloned cDNA sequences, ii) for efl $\alpha$ and $40 s$ based on sequences available in Genbank nucleotide database, and iii) for diol, dio3 and $18 \mathrm{~s}$ based on sequences available in the European eel transcriptome EeelBase 2.0 database (http://compgen.bio.unipd.it/eeelbase/), as indicated in Table 1. To design the primers of dio2 a European eel predicted cDNA sequence was used and the size of the amplicon obtained by amplification was checked (http://www.zfgenomics.com/sub/eel). All primers were designed for an amplification size ranging from 75 to 200 nucleotides and the amplicons obtained were of the expected size (Table1).

Expression of genes in each larval sample ( 4 parental crosses $\times 2$ replicates $\times 4$ temperatures) were analysed in technical triplicates using the qPCR Biomark ${ }^{\mathrm{TM}}$ HD system (Fluidigm) based on 96.96 (GE chips) dynamic arrays (Miest et al., 2015). In brief, a pre-amplification step was 
performed with a $500 \mathrm{nM}$ primer pool of all primers in TaqMan-PreAmp Master Mix (Applied Biosystems) and $1.3 \mu \mathrm{lcDNA}$ per sample at $10 \mathrm{~min}$ at $95^{\circ} \mathrm{C} ; 14$ cycles: $15 \mathrm{~s}$ at $95^{\circ} \mathrm{C}$ and 4 min at $60^{\circ} \mathrm{C}$. Obtained PCR products were diluted 1:10 with low EDTA-TE buffer. The pre-amplified product was loaded onto the chip with SSofast-EvaGreen Supermix low Rox (Bio Rad) and DNABinding Dye Sample Loading Reagent (Fluidigm). Primers were loaded onto the chip at a concentration of $50 \mu \mathrm{M}$. The chip was run according to the Fluidigm 96.96 PCR protocol with a Tm of $60^{\circ} \mathrm{C}$. The relative quantity of target gene transcripts was normalized against the geometric mean of the three housekeeping genes and analysed using the $\Delta \Delta \mathrm{Ct}$ method (Livak and Schmittgen, 2001). Coefficient of variation (CV) of triplicates was calculated and checked to be $<0.04$ (Hellemans et al., 2007). If CV was found to be $>0.04$, triplicates were checked for outliers and if possible duplicate measurements were used. If the use of duplicates was not possible $(\mathrm{CV}>0.04)$ the whole data point was omitted from the analysis. Moreover, malfunctions on the chip and/or unsuccessful RNA extractions can result in expression failures, as was the case for some samples in this study.

\subsection{Statistical analyses}

All data were analyzed using SAS statistical software (version 9.1; SAS Institute Inc., Cary, North Carolina). Residuals were tested for normality using the Shapiro-Wilk test and homogeneity of variances was tested using a plot of residuals versus fit values (PROC GLOT, SAS Institute 2003). Data were $\log _{10}$ or arcsine square-root-transformed when data deviated from normality and/or homoscedasticity (Zar, 1996).

Statistical models were used to investigate temperature effects on gene expression throughout early larval development [Ages 0 to 18 days post hatch (dph)] and at specific developmental stages 
(Stages 1-3). Across the different temperature treatments, Stage 1 represents the day of hatch, Stage 2 represents the timing of teeth formation, and Stage 3 represents the first-feeding stage (Fig. 1). Together, this allowed us to decipher changes in temperature at real-time and standardized developmental intervals.

To examine the effect of temperature on gene expression throughout early development (real time), we used two statistical approaches. In the first approach, we analyzed the data using a series of mixed-model repeated measures ANOVAs (PROC MIXED; SAS Institute 2003). Models contained the Temperature $\left(16,18,20\right.$ and $\left.22^{\circ} \mathrm{C}\right)$ and Age (0 to $\left.18 \mathrm{dph}\right)$ main effects as well as the Temperature $\times$ Age interaction. Akaike's (AIC) and Bayesian (BIC) information criteria were used to assess which covariance structure (compound symmetry, autoregressive order, or unstructured) was most appropriate (Littell et al., 1996). Temperature and Age were considered fixed, whereas parental cross was considered random. Tukey's post-hoc analyses were used to compare leastsquares means between treatments. If a significant Temperature $\times$ Age interaction was detected the model was decomposed into a series of reduced ANOVA models to determine the effect of Temperature for each Age and of Age for each Temperature. This was the case for dio3 and thraA. The reduced models involved only preplanned comparisons and did not include repeated use of the same data, so a-level corrections for a posteriori comparisons were not necessary.

In the second approach, we examined variation in gene expression, throughout development at each temperature, by fitting either linear, quadratic or cubic equations to the data (PROC REG; SAS Institute 2003). This allowed us to create predictive models to explore the shape of variation throughout development for each temperature. Linear, quadratic and cubic equations were chosen apriori to fit the data based on the available literature (e.g. McDonald, 2009; Sørensen et al., 2016). Final equation selection (linear, quadratic or cubic) was based on an F-statistic: d.f. $\times\left(\mathrm{R}_{\mathrm{j}}{ }_{\mathrm{j}}-\mathrm{R}_{\mathrm{i}}{ }_{\mathrm{i}}\right) /(1$ $-R_{j}{ }_{j}$ ), where: $R^{2}{ }_{i}=$ the $R^{2}$ for the $i$-th order, $R^{2}{ }_{j}=$ the $R^{2}$ for the next higher order, d.f. $_{j}=$ the degrees 
of freedom for the higher-order equation with $\mathrm{j}$ degrees of freedom in the numerator and d.f. $\mathrm{j}=\mathrm{n}-\mathrm{j}$ -1 degrees of freedom in the denominator (McDonald, 2009). Graphs and regressions were prepared in SigmaPlot (Version 13.0).

\section{Results}

\subsection{Cloning and molecular characterization}

In this study, two forms of THR $\alpha$ (termed aaTHR $\alpha \mathrm{A}$ and aaTHR $\alpha \mathrm{B}$ ) as well as two forms of THR $\beta$ (named aaTHR $\beta$ A and aaTHRßB) were cloned in European eel larvae. The full CDS (coding DNA sequence) of the four THRs was sequenced. The nucleotide sequences of aaTHR $\alpha \mathrm{A}$ (GenBank accession number KY082904) and aaTHR $\alpha$ B (accession number KY082905) are 1375bp and 1334 bp long, with an open reading frame (ORF) that codes for a protein of 416 and 435 amino acids respectively, while the nucleotide sequences of aaTHR $\beta$ A (GenBank accession number KY082906) and THRßB (GenBank accession number KY082907) are 1288bp and 1299bp long, coding for 396 and 378 amino acid proteins respectively (see Supplementary material).

\subsection{Phylogenetic analysis}

The phylogenetic tree constructed by the Neighbor-Joining method from multiple sequence alignment of thr amino acid sequences from a range of vertebrates reveals that European eel thro and $t h r \beta$, grouped into two clearly separated clades (99 bootstrap for both clades). In addition, the topology of the phylogenetic tree showed that European eel thr sequences clustered within the 
teleost groupand each time the Japanese eel homolog $t h r$ sequence was the evolutionary closest (Fig. 2).

\subsection{Gene expression}

No larvae survived at $24^{\circ} \mathrm{C}$. Gene expression of selected genes was compared across the other temperature treatments $\left(16,18,20\right.$ and $\left.22^{\circ} \mathrm{C}\right)$ in real time and at specific developmental stages (developmental time). The expression of target genes was affected in real and/or developmental time by larval age (or stage), temperature, and/or their interaction (see specific genes below).

\subsubsection{Deiodinases}

In developmental time, expression of diol significantly $(\mathrm{P}=0.004)$ increased on Stage 2 (teeth formation) and 3 (first-feeding), while no significant $(\mathrm{P}=0.271)$ effect of Temperature was detected (Fig. 3A-B). In real time, gene expression of diol was significantly affected by Temperature $(\mathrm{P}=0.034)$ and Age $(\mathrm{P}<0.0001)$, while no significant Temperature $\times$ Age interaction was detected $(\mathrm{P}=0.903)$. Gene expression of diol significantly increased at $22^{\circ} \mathrm{C}$ (Fig. 3C) and significantly increased throughout ontogeny with increasing larval Age (Fig. 3D). The relationship between Age and diol expression was best explained by a sigmoidal cubic regression at $16^{\circ} \mathrm{C}$ ( Fig. 3E). There were no significant relationships between Age and diol expression (Fig. 3F-H) at the other temperatures.

Similarly, expression of dio2 significantly $(\mathrm{P}=0.008)$ increased on Stage 3 (first-feeding), while no significant effect of Temperature was detected $(P=0.178$; Fig. 3I-J) in developmental time. In real time, gene expression of dio2 increased throughout ontogeny with increasing larval 
Age $(\mathrm{P}<0.0001$; Fig. 3L), while no significant Temperature $(\mathrm{P}=0.088$; Fig. $3 \mathrm{~K})$ or Temperature $\times$ Age interaction $(\mathrm{P}=0.394)$ was detected. The relationships between Age and dio2 expression were best explained by sigmoidal cubic regressions at $16^{\circ} \mathrm{C}, 18^{\circ} \mathrm{C}$ and $20^{\circ} \mathrm{C}$ (Fig. 3M-O). There was no significant relationship between Age and dio 2 expression at $22^{\circ} \mathrm{C}$ (Fig. 3P).

On the other hand, expression of dio3 significantly ( $\mathrm{P}<0.0001)$ increased on Stage 1 (hatch) and was significantly impacted by Temperature $(\mathrm{P}=0.014$; Fig. 3Q-R) when compared in developmental time, as well as significantly affected by the Temperature $\times$ Age interaction $(\mathrm{P}<$ 0.0001) when compared in real time. Thus, the model was decomposed into a series of reduced ANOVA models to determine the effect of Temperature for each Age (Fig. 3S) and of Age for each Temperature (Fig. 3T-W). Significant differences in gene expression of dio3 among temperatures occurred throughout development on $0(\mathrm{P}=0.030), 2(\mathrm{P}=0.019), 10(\mathrm{P}=0.044), 12(\mathrm{P}<0.0001)$ and 14 dph (P=0.006; Fig. 3S). Larval Age significantly influenced gene expression of dio3 when larvae were reared at 16,18 and $20^{\circ} \mathrm{C}(\mathrm{P}<0.0001$; Fig. $3 \mathrm{~T}-\mathrm{V})$, but not at $22^{\circ} \mathrm{C}(\mathrm{P}=0.056$; Fig $3 \mathrm{~W})$. The relationships between Age and dio3 expression can be explained by quadratic parabola regressions at all temperatures investigated (Fig. 3T-W).

\subsubsection{Thyroid hormone receptors}

In developmental time, expression of thraA significantly $(\mathrm{P}<0.0001)$ increased on Stage 2 (teeth formation) and 3 (first-feeding), while no significant $(\mathrm{P}=0.167)$ effect of Temperature was detected (Fig 4A-B). In real time, gene expression of throA was significantly affected by the Temperature $\times$ Age interaction $(\mathrm{P}=0.039)$. Thus, the model was as above decomposed into a series of reduced ANOVA models to determine the effect of Temperature for each Age (Fig. 4C) and of Age for each Temperature (Fig. 4D-G). Significant differences in gene expression of thraA among 
temperatures occurred throughout development on $2(\mathrm{P}=0.033)$ and 8 dph $(\mathrm{P}=0.016$; Fig. 4C). Larval Age significantly influenced gene expression of throA and relationships between Age and throA expression can be explained by linear regressions at $16^{\circ} \mathrm{C}, 20^{\circ} \mathrm{C}$ and $22^{\circ} \mathrm{C}$ (Fig. $4 \mathrm{D}, \mathrm{F}$ and $\mathrm{G})$, or by a sigmoidal cubic regression at $18^{\circ} \mathrm{C}$ (Fig. 4E).

Similar to thraA, expression of thr $\alpha B$ significantly $(\mathrm{P}<0.0001)$ increased on Stage 2 (teeth formation) and 3 (first-feeding), while no significant $(P=0.267)$ effected of Temperature was detected (Fig. 4H-I). In real time, gene expression of thr $\alpha B$ was significantly affected by Temperature $(\mathrm{P}=0.006$; Fig. $4 \mathrm{~J})$ and Age $(\mathrm{P}<0.0001$; Fig. 4K), while no significant Temperature $\times$ Age interaction $(\mathrm{P}=0.147)$ was detected. Gene expression of thr $\alpha B$ significantly increased at $22^{\circ} \mathrm{C}$ (Fig. 4J) and significantly increased (up to 5-fold) throughout ontogeny with increasing larval Age (Fig. 4K). The relationships between Age and thraB expression were best explained by linear regressions at $16^{\circ} \mathrm{C}, 20^{\circ} \mathrm{C}$ and $22^{\circ} \mathrm{C}$ (Fig. $4 \mathrm{~L}, \mathrm{~N}$ and $\mathrm{O}$ ), or by a sigmoidal cubic regression at $18^{\circ} \mathrm{C}$ (Fig. 4M).

In contrast to all the other thrs, expression of $t h r \beta A$ significantly $(\mathrm{P}=0.001)$ decreased from Stage 1 (hatch), while no significant $(\mathrm{P}=0.098)$ effect of Temperature was detected (Fig 5A-B). In real time, gene expression of $t h r \beta A$ was not significantly affected by Temperature $(\mathrm{P}=0.342$; Fig. 5C) and no Temperature $\times$ Age interaction $(\mathrm{P}=0.940)$ was detected. On the contrary, a significant $(\mathrm{P}=0.0003$ ) effect of Age was detected (Fig. 5D). The relationships between Age and thr $\beta A$ expression were best explained by linear regressions at $18^{\circ} \mathrm{C}$ and $22^{\circ} \mathrm{C}$ (Fig. 5F, H). No significant relationships between Age and $t h r \beta A$ expression were detected at 16 and $20^{\circ} \mathrm{C}$ (Fig. 5E, G).

Similar to thros, expression of $t h r \beta B$ significantly $(\mathrm{P}<0.0001)$ increased on Stage 2 (teeth formation) and 3 (first-feeding), while no significant $(\mathrm{P}=0.203)$ effect of Temperature was detected (Fig. 5I-J). In real time, gene expression of thr $\beta B$ was significantly affected by Temperature $(\mathrm{P}=0.012$; Fig. 5K) and larval Age $(\mathrm{P}<0.0001$; Fig. 5L), while no significant 
Temperature $\times$ Age interaction $(\mathrm{P}=0.296)$ was detected. Gene expression of thr $\beta B$ significantly increased at $16^{\circ} \mathrm{C}$ and $22^{\circ} \mathrm{C}$ (Fig. 5K), while significantly increased (up to 6-fold) throughout ontogeny with increasing larval Age (Fig. 5L). The relationships between Age and thr $\beta B$ expression were best explained by linear regressions at $16^{\circ} \mathrm{C}$ and $22^{\circ} \mathrm{C}$ (Fig. $5 \mathrm{M}, \mathrm{P}$ ), or by quadratic parabola regressions at $18^{\circ} \mathrm{C}$ and $20^{\circ} \mathrm{C}(\mathrm{Fig} .5 \mathrm{~N}, \mathrm{O})$.

\section{Discussion}

This study aimed at enhancing our knowledge on the molecular mechanisms controlling European eel early life development. In fish, it has been suggested that THs play a role during the transitional period towards exogenous feeding and that thr expression can be affected by food deprivation (Raine et al., 2005). This study focused solely on the endogenous feeding period, where we investigated the expression patterns of genes encoding for THRs and deiodinases from hatching until first-feeding. Generally and within the thermal tolerance limits of each particular species, increasing temperature accelerates all biochemical processes, causing a shift in early fish development (Martell et al., 2005; Politis et al., 2014b) and gene expression can follow a similar pattern (Politis et al., 2017). In this study, we observed that the warmer the temperature the earlier the expression response of a specific target gene. Thus, even though the expression profiles often appeared very similar and only shifted with temperature (when compared in real time), they were affected (in real and/or developmental time) by larval age (or stage), temperature, and/or their interaction.

In more detail, fish ELH has been correlated to thyroid hormone metabolism, which is under the control of the hypothalamus-pituitary-thyroid axis, where the thyroid gland is synthesizing $\mathrm{TH}$ (Jarque and Piña, 2014). This is regulated by the thyroid stimulating hormone (thyrotropin), which 
is released by the pituitary as a consequence of the thyrotropin-releasing hormone from the hypothalamus (MacKenzie et al., 2009). TH is synthesized as a precursor (T4) with weak bioactivity and can be converted into active hormones (T3) or inactive metabolites (reverse-T3 or T2) by three transmembrane proteins, the iodothyroninedeiodinases (DIO1-3), in peripheral tissues. They selectively remove iodine moieties towards the active forms through the outer and the inactive forms through the inner ring deiodination processes (Jarque and Piña, 2014). Here, we inter alia identified and followed the expression patterns of all three iodothyroninedeiodinase genes (diol-3) during early (yolk-sac) larval stages of experimentally reared (from hatch until first-feeding) European eel. Interestingly, expressions of dio2 and dio3 were elevated at hatch, potentially due to maternal origin (Castillo et al., 1993; Olsen and Press, 1997; Huttenhuis et al., 2006; Swain and Nayak, 2009; Lee et al., 2013), or possibly representing their involvement in specific processes around hatching. Thus, it would be of interest to follow their expression patterns (and the consequences of potential variations) also during embryogenesis and embryonic development, in order to elucidate their role during this sensitive life period. Furthermore, the expression slowly decreased during the first couple of dph until a clear sigmoidal or exponential increase was observed, respectively, For diol, we did not observe a similarly clear pattern in all thermal regimes.

Deiodination in the peripheral tissues of fish has been linked to several functional and vital processes, while showing sensitivity to environmental organic contaminants (Adams et al., 2000; Couderc et al., 2016), as well as physical environmental factors, such as pH (Mol et al., 1998), temperature (Adams et al., 2000), salinity (Orozco et al., 2002), and/or light (Comeau et al., 2000; Wambiji et al., 2011). Temperature has been shown to influence the outer and/or the inner ring deiodination of species, such as rainbow trout, Oncorhynchus mykiss (Johnston and Eales, 1995), blue tilapia, Oreochromis Aureus (Mol et al., 1997), Atlantic cod, Gadus morhua (Cyr et al., 1998; Comeau et al., 2000), American plaice, Hippoglossoides platessoides (Adams et al., 2000) and 
zebrafish (Little et al., 2013). In the present study, we experimentally showed that temperature had a significant effect (in real and/or developmental time) on gene expression related to deiodination activities during early larval development of European eel. Moreover, we showed that the expression of all deiodination genes are significantly affected by the age or stage of eel larvae. Within the thermal tolerance limits, we commonly observed elevated expression towards and within the first-feeding window, which probably corresponds to a timing of refinement for organogenesis (e.g. brain, liver, gastro intestinal tract, etc.) and/or specific functional tissue (e.g. teeth, eyes, etc.), in order to ensure optimal transition from endogenous to exogenous feeding (Sørensen et al., 2016; Butts et al., 2016).

Thyroid hormones are moreover known to regulate the level of THRs, which are members of the steroid hormone receptor superfamily (Evans, 1988). Two subtypes, with isoforms within the subtypes, are found to be products of distinct genes or splice variants of the same gene (Kawakami et al., 2013). In the present work, we have identified and cloned the full CDS of two thro (thraA and $\operatorname{thr} \alpha B$ ) and two $\operatorname{thr} \beta$ (thr $\beta A$ and $\operatorname{thr} \beta B$ ) gene forms in European eel larvae and followed their expression patterns from hatch to the first-feeding stage. All four European eel sequences contain the conserved DBD and LBD domains and two putative zinc fingers, providing evidence that they should be functional (see Supplementary material). The phylogenetic tree constructed, using several THR vertebrate sequences, reveals that European eel thrs are close to their fish orthologs, showing the highest homology (97-99\%) with Japanese eel sequences (Kawakami et al., 2013). In thraB, however, an insertion of 22 amino acids was observed at the N-terminus part (A/B domain), which is missing in the corresponding Japanese eel sequence.

Similarly, to the genes involved in the deiodination process, thrs were affected by both, larval age, and temperature. Expression of $t h r$ genes increased during development, usually in a linear or an exponential fashion, with the exception of $\operatorname{thr} \beta A$ that decreased during development. Similar to 
the expression of deiodinases, expression of thrs was usually high around the first-feeding stages, probably representing the involvement of the THRs towards and during the refinement of organogenesis and specific tissue for an optimal transition to exogenous feeding. Moreover, in real time, temperature was found to impact the expression pattern of thr genes. Generally, increasing temperature caused acceleration in development (Politis et al., 2017) and the warmer the temperature, the earlier the expression response of a specific target gene, potentially corresponding to the timing of specific ontogenic development. Interestingly, the expression of $\operatorname{thr} \beta A$ showed a slight increase at the first sampling points (hatch), which could theoretically be due to maternal origin (Castillo et al., 1993; Olsen and Press, 1997; Huttenhuis et al., 2006; Swain and Nayak, 2009; Lee et al., 2013), while it remained low during the rest of the investigated developmental period. This could imply that $t h r \beta A$ genes are not involved in ontogenic development of the ELH stages but potentially gain functionality during the later and/or adult stages of this species, as it has been presented for the related Japanese conger eel (Kawakami et al., 2003a,b) and Japanese eel (Kawakami et al., 2013).

In conclusion, we cloned and characterized thr sequences, followed the expression pattern of thrs and dios, and showed that temperature affected the expression of those genes in artificially produced ELH stages of European eel, reared in different thermal regimes from hatch until firstfeeding. We identified 2 subtypes of $t h r(t h r \alpha$ and $t h r \beta)$ with 2 isoforms each (thr $\alpha A$, thr $\alpha B$, thr $\beta A$ and $t h r \beta B$ ) and 3 subtypes of deiodinases (diol, dio2 and dio3). All thr genes identified, show high similarity to other mammalian, bird, amphibian or fish species, with highest similarity to the closely related Japanese eel. We can confidently state that all genes investigated in this study, involved in the mediation of $\mathrm{TH}$ action, were significantly affected (in real and/or developmental time) by larval age, temperature, and/or their interaction. Finally, we demonstrate that thrs and dios show sensitivity to temperature and are involved in and during early life development of European eel. 


\section{Acknowledgements}

This study was part of the project Eel Hatchery Technology for a Sustainable Aquaculture (EELHATCH) supported financially by InnovationFund Denmark, Grant no. 11-2013-3. Politis SN, received travel grants from the COST Office (Food and Agriculture COST Action FA1205: Assessing and improving the quality of aquatic animal gametes to enhance aquatic resources. The need to harmonize and standardize evolving methodologies, and improve transfer from academia to industry; AQUAGAMETE). Butts, IAE was partially supported by the Alabama Agricultural Experiment Station and the Hatch program of the National Institute of Food and Agriculture, U.S. Department of Agriculture. Miest JJ, was funded by the FINEAQUA-project (Program for the future - economy, Schleswig-Holstein - European regional development fund (ERDF)). The funding sources had no involvement in the preparation of the article, study design, the collection, analysis and interpretation of data, the writing of the report, or the decision to submit the article for publication. We would like to thank Peter Lauesen (Billund Aquaculture Service A/S), Maria Krüger-Johnsen (Danish Technical University) and Christian Graver (Danish Aquaculture Organisation) for assistance with broodstock management, Lauriane Madec (French Research Institute for Exploitation of the Sea) for assistance during laboratory work and Helene Rønquist Knutsen (Norwegian University of Science and Technology) for assistance during experimental work. Lastly, we would like to thank anonymous reviewers for valuable edits that have improved this manuscript.

\section{References}


Abel, E.D., Boers, M.-E., Moura, C.P., Moura, E., Kaulbach, H., Zakaria, M., Lowell, B., Radovick, S., Liberman, M.C., Wondisford, F., 1999. Divergent roles for thyroid hormone receptor b isoforms in the endocrine axis and auditory system. J. Clin. Invest.104, 291-300.

Adams, B.A., Cyr, D.G., Eales, J.G., 2000. Thyroid hormone deiodination in tissues of American plaice, Hippoglossoides platessoides: characterization and short-term responses to polychlorinated biphenyls (PCBs) 77 and 126. Comp. Biochem. Physiol. C Toxicol. Pharmacol. 127, 367-378.

Ahn, H., Yamada, Y., Okamura, A., Horie, N., Mikawa, N., Tanaka, S., Tsukamoto, K., 2012. Effect of water temperature on embryonic development and hatching time of the Japanese eel Anguilla japonica. Aquaculture. 330-333, 100-105.

Bertrand, S., Thisse, B., Tavares, R., Sachs, L., Chaumot, A., Bardet, P.-L., Escrivà, H., Duffraisse, M., Marchand, O., Safi, R., Thisse, C., Laudet, V., 2007. Unexpected novel relational links uncovered by extensive developmental profiling of nuclear receptor expression. PLoS Genetics. 3(11), 2085-2100.

Bonhommeau, S., Chassoti, E., Rivot, E., 2008. Fluctuations in European eel (Anguilla anguilla) recruitment resulting from environmental changes in the Sargasso Sea. Fish. Oceanogr. 17(1), $32-44$.

Burge, C., Karlin, S., 1997. Prediction of complete gene structures in human genomic DNA. J. Mol. Biol. 268(1), 78-94.

Butts, I.A.E., Sørensen, S.R., Politis, S.N., Pitcher, T.E., Tomkiewicz, J., 2014. Standardization of fertilization protocols for the European eel. Aquaculture. 426-427, 9-13.

Butts, I.A.E., Sørensen, S.R., Politis, S.N., Tomkiewicz, J., 2016. First-feeding by European eel larvae: A step towards closing the life cycle in captivity. Aquaculture. 464, 451-458. 
Campinho, M.A., Galay-Burgos, M., Sweeney, G.E., Power, D.M., 2010. Coordination of deiodinase and thyroid hormone receptor expression during the larval to juvenile transition in sea bream (Sparus aurata, Linnaeus). Gen. Comp. Endocrinol. 165(2), 181-94.

Castillo, A., Sánchez, C., Dominguez, J., Kaattari, S.L., Villena, A.J., 1993. Ontogeny of IgM and IgM-bearing cells in rainbow trout. Dev. Comp. Immunol. 17, 419-424.

Castonguay, M., McCleave, J.D., 1987. Vertical distributions, diel and ontogenetic vertical migrations and net avoidance of leptocephali of Anguilla and other common species in the Sargasso Sea. J. Plankton Res. 9(I), 195-214.

Comeau, L.A., Campana, S.E., Hanson, J.M., Chouinard, G.A., 2000. Seasonal changes of thyroid hormones in field-collected Atlantic cod in relation to condition indices, water temperature and photoperiod. J. Fish Biol. 57, 571-588.

Cook, C.B., Kakucska, I., Lechan, R.M., Koenig, R.J., 1992. Expression of thyroid hormone receptor b2 in rat hypothalamus. Endocrinology. 130, 1077-1079.

Couderc, M., Marchand, J., Zalouk-Vergnoux, A., Kamari, A., Moreau, B., Blanchet-Letrouvé, I., Le Bizec, B., Mouneyrac, C., Poirier, L., 2016. Thyroid endocrine status of wild European eels (Anguilla anguilla) in the Loire (France). Relationships with organic contaminant body burdens. Sci. Total Environ. 550, 391-405.

Cyr, D.G., Idler, D.R., Audet, C., McLeese, J.M., Eales, J.G., 1998. Effects of long-term temperature acclimation on thyroid hormone deiodinase function, plasma thyroid hormone levels, growth, and reproductive status of male Atlantic cod, Gadus morhua. Gen. Comp. Endocrinol. 109, 24-36.

da Silva, F.F.G., Støttrup, J.G., Kjørsvik, E., Tveiten, H., Tomkiewicz, J., 2016. Interactive effects of dietary composition and hormonal treatment on reproductive development of cultured female European eel, Anguilla anguilla. Anim. Reprod. Sci. 171, 17-26. 
Davis, P.J., Leonard, J.L., Davis, F.B., 2009. Mechanisms of nongenomic actions of thyroid hormone. Front. Neuroendocrinol. 29(2), 211-8.

Evans, R.M., 1988. The steroid and thyroid hormone receptor superfamily. Science. 240, 889-895.

Friedland, K.D., Miller, M.J., Knights, B., 2007. Oceanic changes in the Sargasso Sea and declines in recruitment of the European eel. ICES J. Mar. Sci. 64, 519-530.

Geeraerts, C., Belpaire, C., 2010. The effects of contaminants in European eel: a review. Ecotoxicology. 19, 239-266.

Hellemans, J., Mortier, G., De Paepe, A., Speleman, F., Vandesompele, J., 2007. qBase relative quantification framework and software for management and automated analysis of real-time quantitative PCR data. Genome Biology. 8(2), R19.

Henkel, C.V., Burgerhout, E., de Wijze, D.L., Dirks, R.P., Minegishi, Y., Jansen, H.J., Spaink, H.P., Dufour, S., Weltzien, F.-A., Tsukamoto, K., van den Thillart, G.E.E.J.M., 2012. Primitive Duplicate Hox Clusters in the European Eel's Genome. PLoS One. 7(2): e32231.

Hsu, H.-Y., Chen, S.-H., Cha, Y.-R., Tsukamoto, K., Lin, C.-Y., Han, Y.-S., 2015. De Novo Assembly of the Whole Transcriptome of the Wild Embryo, Preleptocephalus, Leptocephalus, and Glass Eel of Anguilla japonica and Deciphering the Digestive and Absorptive Capacities during Early Development. PLoS ONE 10(9): e0139105. doi:10.1371/journal.pone.0139105.

Hodin, R.A., Lazar, M.A., Wintman, B.I., Darling, D.S., Koenig, R.J., Larsen, P.R., Moore, D.D. Chin, W.W., 1989. Identification of a thyroid hormone receptor that is pituitary-specific. Science. 244(4900), 76-79.

Huttenhuis, H.B.T., Grou, C.P.O., Taverne-Thiele, A.J., Taverne, N., Rombout, J.H.W.M., 2006. Carp (Cyprinus carpio L.) innate immune factors are present before hatching. Fish Shellfish Immunol. 20, 586-596. 
ICES report of the joint EIFAAC/ICES/GFCM working group on eel (WGEEL) 2015. ICES advisory committee. ICES CM 2015/ACOM:18. REF. ACOM, WG RECORDS, SSGEF AND FAO, EIFAAC AND GFCM. 24 November-2 December 2015. Antalya, Turkey. Last accessed on 19.06.2017. Available here:

http://ices.dk/sites/pub/Publication\%20Reports/Expert\%20Group\%20Report/acom/2015/WG EEL/wgeel_2015_final.pdf

Infante, C., Asensio, E., Cañavate, J.P., Manchado, M., 2008. Molecular characterization and expression analysis of five different elongation factor 1 alpha genes in the flatfish Senegalese sole (Solea senegalensis Kaup): differential gene expression and thyroid hormones dependence during metamorphosis. BMC Mol. Biol. 9, 19.

Jacoby, D., Gollock, M., 2014. Anguilla anguilla. The IUCN Red List of Threatened Species 2014: e.T60344A45833138. Last accessed on 19.06.2017. Available here: http://www.iucnredlist.org/details/60344/0

Jarque, S., Piña, B., 2014. Deiodinases and thyroid metabolism disruption in teleost fish. Environ. Res. 135, 361-375.

Johnston, C.E., Eales, J.G., 1995. Effects of acclimation and assay temperature on outer- and innerring thyroxine and 3,5,3'-triiodo-L-thyronine deiodination by liver microsomes of rainbow trout, Oncorhynchus mykiss. J. Exp. Zool. 272, 426-434.

Jones, D.T., Taylor, W.R., Thornton, J.M., 1992. The rapid generation of mutation data matrices from protein sequences. Comput. Appl. Biosci. 8, 275-282.

Jones, I., Rogers, S.A., Kille, P., Sweeney, G.E., 2002. Molecular cloning and expression of thyroid hormone receptor a during salmonid development. Gen. Comp. Endocrinol. 125, 226-235. 
Kagawa, H., Tanaka, H., Ohta, H., Unuma, T., Nomura, K., 2005. The first success of glass eel production in the world: basic biology on fish reproduction advances new applied technology in aquaculture. Fish Physiol. Biochem. 31, 193-199.

Kawakami, Y., Tanda, M., Adachi, S., Yamauchi, K., 2003. cDNA cloning of thyroid hormone receptor betas from the conger eel, Conger myriaster. Gen. Comp. Endocrinol. 131, 232-240.

Kawakami, Y., Nomura, K., Ohta, H., Tanaka, H., 2013. Characterization of thyroid hormone receptors during early development of the Japanese eel (Anguilla japonica). Gen. Comp. Endocrinol. 194, 300-310.

Köhrle, J., 2000. The deiodinase family: selenoenzymes regulating thyroid hormone availability and action. Cell. Mol. Life Sci. 57, 1853-1863.

Koenig, R.J., Lazar, M.A., Hodin, R.A., Brent, G.A., Larsen, P.R., Chin, W.W., Moore, D.D., 1989. Inhibition of thyroid hormone action by a non-hormone binding c-erbA protein generated by alternative mRNA splicing. Nature. 337, 659-661.

Lazar, M.A., Hodin, R.A., Chin, W.W., 1989. Human carboxylterminal variant of alpha-type cerbA inhibits transactivation by thyroid hormone receptors without binding thyroid hormone. Proc. Natl. Acad, Sci. 86(20), 7771-7774.

Lazar, M.A., 1993. Thyroid hormone receptors: multiple forms, multiple possibilities. Endocrinol. Rev. 14, 184-193.

Lee, J.-W., Lee, Y.M., Lee, J.-H., Noh, J.K., Kim, H.C., Park, C.-J., Park, J.-W., Hwang, I.J., Kim, S.Y., 2013. The Expression Analysis of Complement Component C3 during Early Developmental Stages in Olive Flounder (Paralichthys olivaceus). Dev. Reprod. 17, 311-319. Littell, R.C., Milliken, G.A., Stroup, W.W., Wolfinger, R.D., 1996. SAS system for mixed models. Cary, North Carolina: SAS Institute Incorporated. 
Little, A.G., Kunisue, T., Kannan, K., Seebacher, F., 2013. Thyroid hormone actions are temperature-specific and regulate thermal acclimation in zebrafish (Danio rerio). BMC Biol. $11,26$.

Liu, Y.-W., Lo, L.-J., Chan, W.-K., 2000. Temporal expression and T3 induction of thyroid hormone receptors a1 and b1 during early embryonic and larval development in zebrafish, Danio rerio. Mol. Cell. Endocrinol. 159, 187-195.

Livak, K.J., Schmittgen, T.D., 2001. Analysis of relative gene expression data using real-time quantitative PCR and the $2^{-\Delta \Delta C}$ Method. Methods. 25(4), 402-408.MacKenzie, D.S., Jones, R.A., Miller, T.C., 2009. Thyrotropin in teleost fish. Gen. Comp. Endocrinol. 161, 83-89.

Marchand, O., Safi, R., Escriva, H., Van Rompaey, E., Prunet, P., Laudet, V., 2001. Molecular cloning and characterization of thyroid hormone receptors in teleost fish. J. Mol. Endocrinol. 26(1), 51-65.

Marchand, O., Duffraisse, M., Triqueneaux, G., Safi, R., Laudet, V., 2004. Molecular cloning and developmental expression patterns of thyroid hormone receptors and T3 target genes in the turbot (Scophtalmus maximus) during postembryonic development. Gen. Comp. Endocrinol. $135,345-357$.

Martell, D.J., Kieffer, J.D., Trippel, E.A., 2005. Effects of temperature during early life history on embryonic and larval development and growth in haddock. J. Fish Biol. 66, 1558-1575.

Masuda, Y., Imaizumi, H., Oda, K., Hashimoto, H., Usuki, H., Teruya, K., 2012. Artificial completion of the Japanese eel, Anguilla japonica, life cycle: challenge to mass production. Bull. Fish. Res. Agen. 35, 111-117.

McDonald, J.H., 2009. Handbook of biological statistics, 2nd edition. Baltimore, Maryland: Sparky House Publishing. 
Miest, J.J., Arndt, C., Adamek, M., Steinhagen, D., Reusch, T.B.H., 2015. Dietary $\beta$-glucan (MacroGard®) enhances survival of first feeding turbot (Scophthalmus maximus) larvae by altering immunity, metabolism and microbiota. Fish Shellfish Immunol. 48, 94-104.

Miller, M.J., 2009. Ecology of Anguilliform leptocephali: remarkable transparent fish larvae of the ocean surface layer. Aqua-Bio Sci. Monogr. 2, 1-94.

Miller, M.J., Bonhommeau, S., Munk, P., Castonguay, M., Hanel, R., McCleave, J.D., 2015. A century of research on the larval distributions of the Atlantic eels: a re-examination of the data. Biol. Rev. Camb. Philos. Soc. 90(4), 1035-1064.

Mol, K.A., Van Der Geyten, S., Darras, V.M., Visser, T.J., Kühn, E.R., 1997. Characterization of iodothyronine outer ring and inner ring deiodinase activities in the blue tilapia, Oreochromis aureus. Endocrinology. 138(5), 1787-1793.

Mol, K.A., Van Der Geyten, S., Burel, C., Kühn, E.R., Boujard, T., Darras, V.M., 1998. Comparative study of iodothyronine outer ring and inner ring deiodinase activities in five teleostean fishes. Fish Physiol. Biochem. 18, 253-266.

Müller, A.V., McEvoy, F., Tomkiewicz, J., Politis, S.N., Amigo, J.M., 2016. Ultrasonographic predictors of response of European eels (Anguilla anguilla) to hormonal treatment for induction of ovarian development. Am. J. Vet. Res. 77(5), 478-486.

Nelson, E.R., Habibi, H.R., 2009. Thyroid receptor subtypes: structure and function in fish. Gen. Comp. Endocrinol. 161(1), 90-6.

Nowell, M.A., Power, D.M., Canario, A.V.M., Llewellyn, L., Sweeney, G.E., 2001. Characterization of a sea bream (Sparus aurata) thyroid hormone receptor- $\beta$ clone expressed during embryonic and larval development. Gen. Comp. Endocrinol. 123, 80-89. 
Ohta, H., Kagawa, H., Tanaka, H., Okuzawa, K., Hirose, K., 1996. Changes in fertilization and hatching rates with time after ovulation induced by 17,20ß-dihydroxy-4-pregnen-3-one in the Japanese eel, Anguilla japonica. Aquaculture. 139, 291-301.

Okamura, A., Yamada, Y., Horie, N., Utoh, T., Mikawa, N., Tanaka, S., Tsukamoto, K., 2007. Effects of water temperature on early development of Japanese eel Anguilla japonica. Fish. Sci. $73,1241-1248$

Olsen, Y., Press, C.M., 1997. Degradation kinetics of immunoglobulin in the egg, alevin and fry of Atlantic salmon, Salmo salar L., and the localisation of immunoglobulin in the egg. Fish Shellfish Immunol. 7, 81-91.

Orozco, A., Villalobos, P., Valverde-R., C., 2002. Environmental salinity selectively modifies the outer-ring deiodinating activity of liver and kidney in the rainbow trout. Comp. Biochem. Physiol. A. 131, 387-395.

Peñaranda, D.S., Pérez, L., Gallego, V., Barrera, R., Jover, M., Asturiano, J.F., 2010. European Eel sperm diluent for short-term storage. Reprod. Domest. Anim. 45, 407-415.

Politis, S.N., Butts, I.A.E., Tomkiewicz, J., 2014a. Light impacts embryonic and early larval development of the European eel, Anguilla anguilla. J. Exp. Mar. Biol. Ecol. 461, 407-415.

Politis, S.N., Dahlke, F.T., Butts, I.A.E., Peck, M.A., Trippel, E.D., 2014b. Temperature, paternity and asynchronous hatching influence early developmental characteristics of larval Atlantic cod, Gadus morhua. J. Exp. Mar. Biol. Ecol. 459, 70-79.

Politis, S.N., Mazurais, D., Servili, A., Zambonino-Infante, J.-L., Miest, J.J., Sørensen, S.R., Tomkiewicz, J., Butts, I.A.E., 2017. Temperature effects on gene expression and morphological development of European eel, Anguilla anguilla larvae. PLoS ONE. 12(8), e0182726. 
Power, D.M., Llewellyn, L., Faustino, M., Nowell, M.A., Bjornsson, B.T., Einarsdottir, I.E., Canario, A.V., Sweeney, G.E., 2001. Thyroid hormones in growth and development of fish. Comp. Biochem. Physiol. C. 130, 447-459.

Righton, D., Westerberg, H., Feunteun, E., Økland, F., Gargan, P., Amilhat, E., Metcalfe, J., LobonCervia, J., Sjöberg, N., Simon, J., Acou, A., Vedor, M., Walker, A., Trancart, T., Brämick, U., Aarestrup, K., 2016. Empirical observations of the spawning migration of European eels: The long and dangerous road to the Sargasso Sea. Sci. Adv. 2, e1501694.

Rozenfeld, C., Butts, I.A.E., Tomkiewicz, J., Zambonino-Infante, J.-L., Mazurais, D., 2016. Abundance of specific mRNA transcripts impacts hatching success in European eel, Anguilla anguilla L. Comp. Biochem. Physiol. A. 191, 59-65.

Saitou, N., Nei, M., 1987. The neighbor-joining method: a new method for reconstructing phylogenetic trees. Mol. Biol. Evol. 4, 406-425.

Sørensen, S.R., Skov, P.V., Lauesen, P., Tomkiewicz, J., Bossier, P., De Schryver, P., 2014. Microbial interference and potential control in culture of European eel (Anguilla anguilla) embryos and larvae. Aquaculture. 426-427, 1-8.

Sørensen, S.R., Tomkiewicz, J., Munk, P., Butts, I.A.E., Nielsen, A., Lauesen, P., Graver, C., 2016. Ontogeny and growth of early life stages of captive-bred European eel. Aquaculture. 456, 5061.

Swain, P., Nayak, S.K., 2009. Role of maternally derived immunity in fish. Fish Shellfish Immunol. 27, 89-99.

Takayama, S., Hostick, U., Haendel, M., Eisen, J., Darimont, B., 2008. An F-domain introduced by alternative splicing regulates activity of the zebrafish thyroid hormone receptor $\alpha$. Gen. Comp. Endocrinol. 155(1), 176-189. 
Tamura, K., Stecher, G., Peterson, D., Filipski, A., Kumar, S., 2013. MEGA6: molecular evolutionary genetics analysis version 6.0. Mol. Biol. Evol. 30, 2725-2729.

Tanaka, H., Kagawa, H., Ohta, H., 2001. Production of leptocephali of Japanese eel (Anguilla japonica) in captivity. Aquaculture. 201, 51-60.

Tanaka, H., Kagawa, H., Ohta, H., Unuma, T., Nomura, K., 2003. The first production of glass eel in captivity: fish reproductive physiology facilitates great progress in aquaculture. Fish Physiol Biochem. 28, 493-497.

Tanaka, H., 2015. Progression in artificial seedling production of Japanese eel Anguilla japonica. Fish. Sci. 81, 11-19.

Tata, J.R., 2000. Autoinduction of nuclear hormone receptors during metamorphosis and its significance. Insect Biochem. Mol. Biol. 30, 645-651.

Tomkiewicz, J., 2012. Reproduction of European Eel in Aquaculture (REEL): Consolidation and New Production Methods. DTU Aqua Report No 249-2012. National Institute of Aquatic Resources, Technical University of Denmark, 1-47.

Van Ginneken, V.J.T., Maes, G.E., 2005. The European eel (Anguilla anguilla, Linnaeus), its lifecycle, evolution and reproduction: a literature review. Rev. Fish Biol. Fisheries. 15, 367398.

Walpita, C.N., Van der Geyten, S., Rurangwa, E., Darras, V.M., 2007. The effect of 3, 5, 30-triiodothyronine supplementation on zebrafish (Danio rerio) embryonic development and expression of iodothyronine deiodinases and thyroid hormone receptors. Gen. Comp. Endocrinol. 152, 206-214.

Wambiji, N., Park, Y.-J., Kim, S.-J., Hur, S.-P., Takeuchi, Y., Takemura, A., 2011. Expression of type II iodothyronine deiodinase gene in the brain of a tropical spinefoot, Siganus guttatus. Comp. Biochem. Physiol. A. 160, 447-452. 
Warner, A., Mittag, J., 2012. Thyroid hormone and the central control of homeostasis. J. Mol. Endocrinol. 49(1), R29-35.

Yamano, K., Inui, Z., 1995. cDNA cloning of thyroid hormone receptor $\beta$ for the Japanese flounder. Gen. Comp. Endocrinol. 99, 197-203.

Yamano, K., Nomura, K., Tanaka, H., 2007. Development of thyroid gland and changes in thyroid hormone levels in Leptocephali of Japanese Eel (Anguilla japonica). Aquaculture. 270(1-4), 499-504.

Zar, J.H., 1996. Biostatistical Analysis. third ed. Prentice-Hall: New Jersey. 
Table 1: Sequences of European eel, Anguilla anguilla primers used for amplification of genes by qRT-PCR. Primers were designed from cloned THR cDNA sequences and other sequences available in GenBank Nucleotide, the European eel transcriptome database (EeelBase 2.0, http://compgen.bio.unipd.it/eeelbase/) or the eel genome website (http://www.zfgenomics.com/sub/eel). The table lists accession number and corresponding database of target gene sequences.

\begin{tabular}{|c|c|c|c|c|}
\hline Full name & Abbreviation & Databases & $\begin{array}{l}\text { Accession } \\
\text { Numbers }\end{array}$ & $\begin{array}{l}\text { Primer sequence }\left(5^{\prime}-3^{\prime}\right) \\
\text { (F: Forward; R: Reverse) }\end{array}$ \\
\hline Deiodinase 1 & diol & EeelBase 2.0 & Eeel2-c186 & $\begin{array}{l}\text { F: AGCTTTGCCAGAACGACTGT } \\
\text { R: TTCCAGAACTCTTCGCACCT }\end{array}$ \\
\hline Deiodinase 2 & dio2 & wel & g12347 & $\begin{array}{l}\text { F: GAAGAGGAGGATCGCCTACC } \\
\text { R: GCACTCTACCTCCGTCCAAA }\end{array}$ \\
\hline Deiodinase 3 & dio3 & EeelBase 2.0 & Eeel-c22164 & $\begin{array}{l}\text { F: TACGGGGCGTATTTTGAGAG } \\
\text { R: GCTATAACCCTCCGGACCTC }\end{array}$ \\
\hline $\begin{array}{l}\text { Thyroid Hormone } \\
\text { Receptor alpha A }\end{array}$ & 4 & $\begin{array}{l}\text { GenBank } \\
\text { Nucleotide }\end{array}$ & KY082904 & $\begin{array}{l}\text { F: GCAGTTCAACCTGGACGACT } \\
\text { R: CCTGGCACTTCTCGATCTTC }\end{array}$ \\
\hline $\begin{array}{l}\text { Thyroid Hormone } \\
\text { Receptor alpha B }\end{array}$ & & $\begin{array}{l}\text { GenBank } \\
\text { Nucleotide }\end{array}$ & KY082905 & $\begin{array}{l}\text { F: GAAGCCTTCAGCGAGTTCAC } \\
\text { R: ACAGCCTTTCAGGAGGATGA }\end{array}$ \\
\hline $\begin{array}{l}\text { Thyroid Hormone } \\
\text { Receptor beta A }\end{array}$ & $B A$ & $\begin{array}{l}\text { GenBank } \\
\text { Nucleotide }\end{array}$ & KY082906 & $\begin{array}{l}\text { F: AGGAACCAATGCCAAGAATG } \\
\text { R: GCCTGTTCTCCTCAATCAGC }\end{array}$ \\
\hline $\begin{array}{l}\text { Thyroid Hormone } \\
\text { Receptor beta B }\end{array}$ & $\operatorname{thr} \beta B$ & $\begin{array}{l}\text { GenBank } \\
\text { Nucleotide }\end{array}$ & KY082907 & $\begin{array}{l}\text { F: GAAGACTGAGCCCTGAGGTG } \\
\text { R: AGGTAATGCAGCGGTAATGG }\end{array}$ \\
\hline $\begin{array}{l}\text { Elongation Factor 1- } \\
\text { alpha }\end{array}$ & efla & $\begin{array}{l}\text { GenBank } \\
\text { Nucleotide }\end{array}$ & EU407824.1 & $\begin{array}{l}\text { F: CTGAAGCCTGGTATGGTGGT } \\
\text { R: CATGGTGCATTTCCACAGAC }\end{array}$ \\
\hline $\begin{array}{l}\text { Ribosomal 18S } \\
\text { RNA }\end{array}$ & $18 s$ & EeelBase 2.0 & eeel2_s7245 & $\begin{array}{l}\text { F: AGAGCAGGGGAACTGACTGA } \\
\text { R: ACCTGGCTGTATTTGCCATC }\end{array}$ \\
\hline $\begin{array}{l}\text { Ribosomal 40S } \\
\text { RNA }\end{array}$ & $40 s$ & $\begin{array}{l}\text { GenBank } \\
\text { TSA }\end{array}$ & GBXM01005349.1 & $\begin{array}{l}\text { F: TGACCGATGATGAGGTTGAG } \\
\text { R: GTTTGTTGTCCAGACCGTTG }\end{array}$ \\
\hline
\end{tabular}




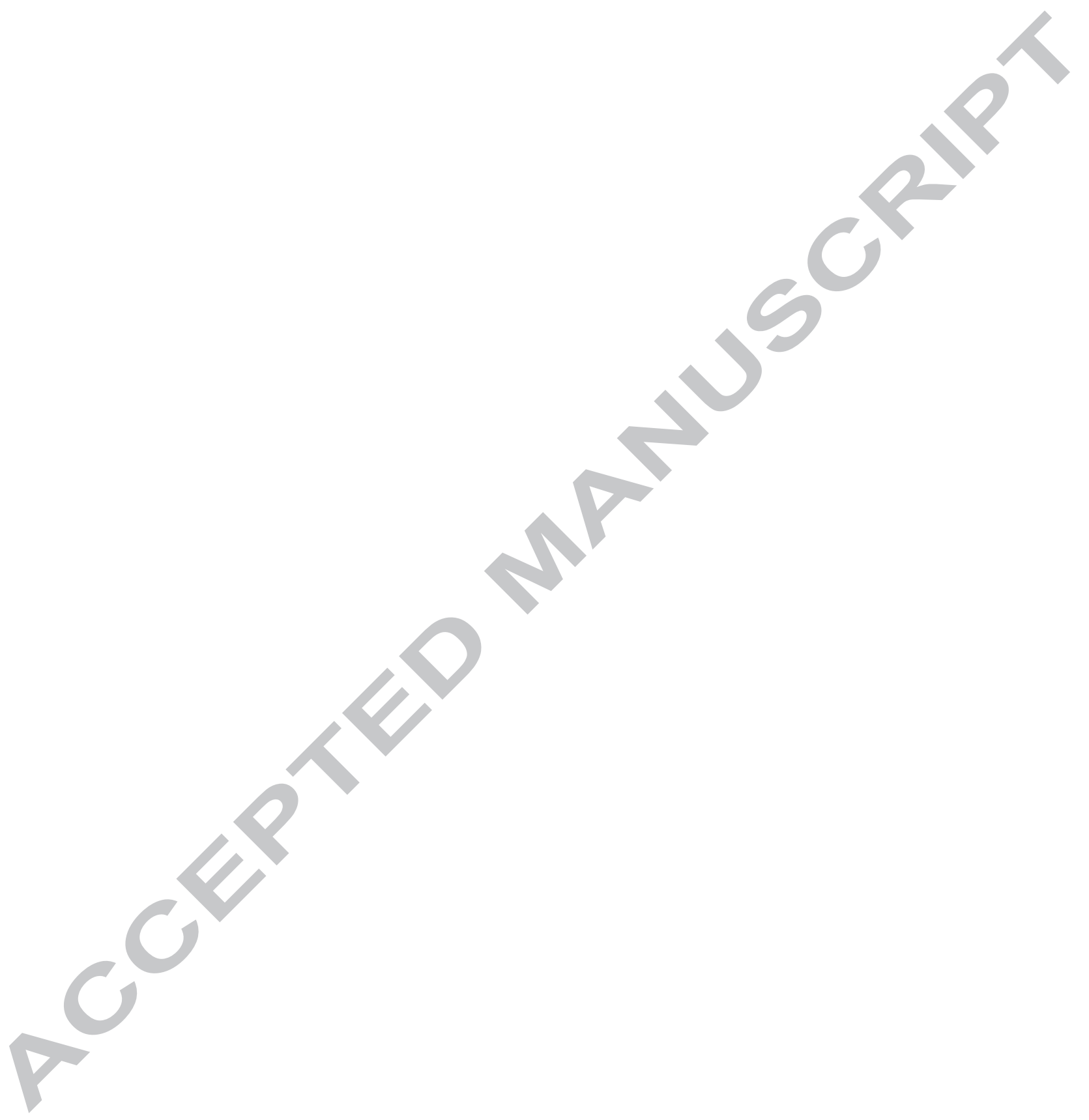


Fig. 1: Stage specific European eel larval development at $18^{\circ} \mathrm{C}$ in days post hatch (DPH) and hours post fertilization (HPF). Stage 1 represents hatching, Stage 2 represents teeth formation, and Stage 3 represents first-feeding. 
Fig. 2: Phylogenetic relationships among thyroid hormone receptors (THRs) of four vertebrate classes were inferred using the Neighbor-Joining method. Fish orders are in italics. The sequences of European eel, Anguilla anguilla obtained in this work are underlined. The percentages of replicate trees in which the associated taxa are clustered together in the bootstrap test (1000 replicates) are shown next to the branches. The tree is drawn to scale, with branch lengths in the same units as those of the evolutionary distances used to infer the phylogenetic tree. The evolutionary distances were computed using the JTT matrix-based method and are in the units of the number of amino acid substitutions per site. All positions containing gaps and missing data were eliminated. Phylogenetic analysis was conducted in MEGA6. S or L in the sequence's name stands for small and large protein forms. The mention tr indicates sequences of truncated proteins. Partial sequences have been omitted. 
Fig. 3: Effect of temperature on larval European eel, Anguilla anguilla gene expression of diol (AB), dio2 (I-J) or dio3 (Q-R) at specific developmental Stages (1: hatch, 2: teeth formation and 3: first-feeding) and diol(C-D), dio2 (K-L) or dio3 (S) in real time, as well as effect of age on dio1 (EH), dio2 (M-P) or dio3 (T-W) expression at each temperature. Data points with an asterisk (*) were not included in the statistical model due to insufficient sample size. Values represent means $( \pm$ SEM) among 4 crosses at each temperature. Means were contrasted using the Tukey-Kramer method and treatments with the same letters are not significantly different $(P>0.05)$. 
Fig. 4: Effect of temperature on larval European eel, Anguilla anguilla gene expression of thraA (AB) or thr $\alpha B$ (H-I) at specific developmental stages (1: hatch, 2: teeth formation and 3: first-feeding) and $\operatorname{thr} \alpha A(\mathrm{C})$ or $\operatorname{thr} \alpha B(\mathrm{~J}-\mathrm{K})$ in real time, as well as effect of age on thraA (D-G) or thr $\alpha B$ expression (L-O) at each temperature. Data points with an asterisk $(*)$ were not included in the statistical model due to insufficient sample size. Values represent means ( \pm SEM) among 4 crosses at each temperature. Means were contrasted using the Tukey-Kramer method and treatments with the same letters are not significantly different $(P>0.05)$. 
Fig. 5: Effect of temperature on larval European eel, Anguilla anguilla gene expression of thr $\beta A$ (AB) or $\operatorname{thr} \beta B$ (I-J) at specific developmental stages (1: hatch, 2: teeth formation and 3: first-feeding) and $\operatorname{thr} \beta A(\mathrm{C}-\mathrm{D})$ or $\operatorname{thr} \beta B(\mathrm{~K}-\mathrm{L})$ in real time, as well as effect of age on $\operatorname{thr} \beta A(\mathrm{E}-\mathrm{H})$ or $\operatorname{thr} \beta B$ expression (M-P) at each temperature. Values represent means $( \pm$ SEM) among 4 crosses at each temperature. Means were contrasted using the Tukey-Kramer method and treatments with the same letters are not significantly different $(\mathrm{P}>0.05)$.

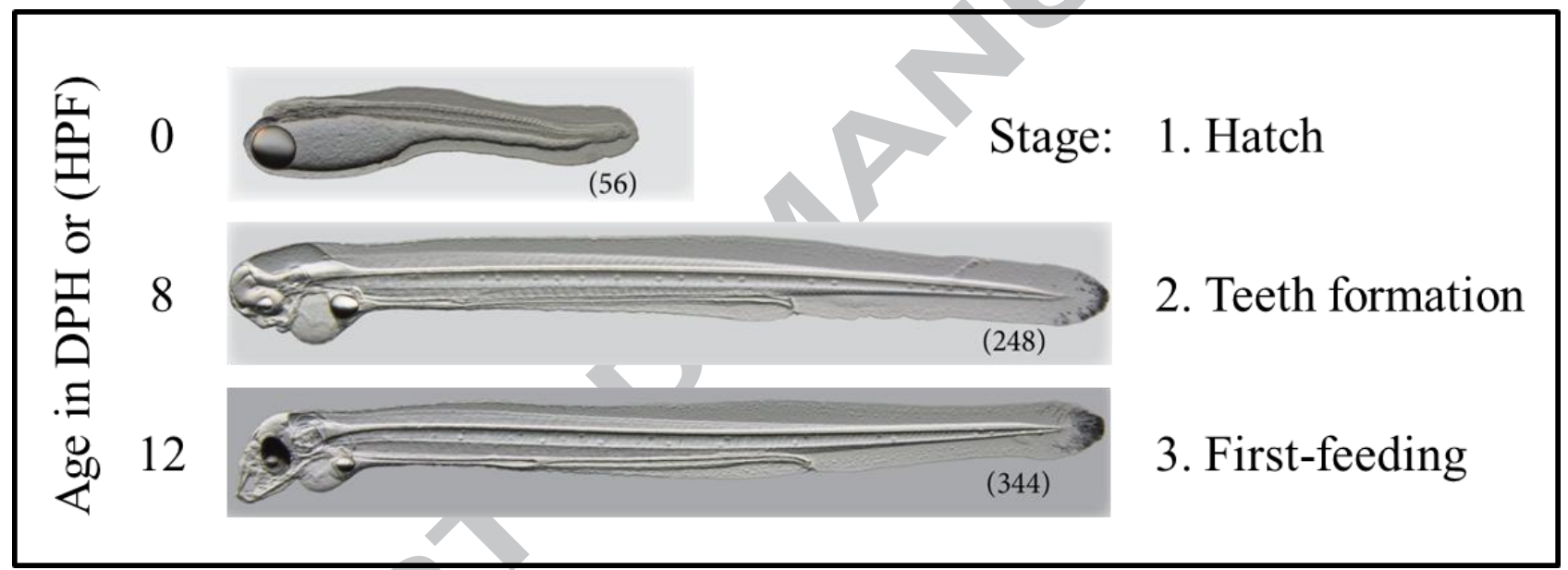

Figure_1 


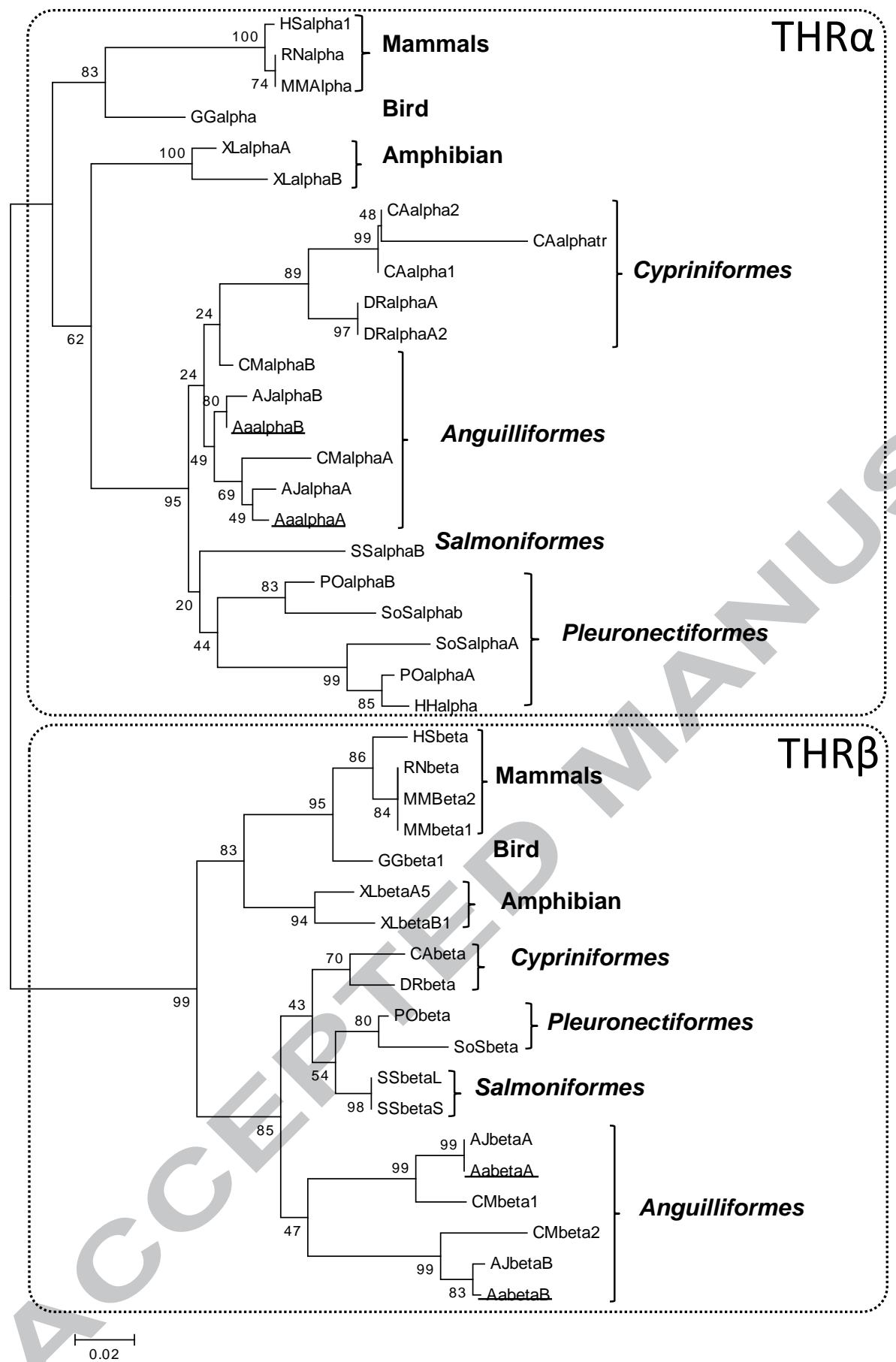

Figure_2 


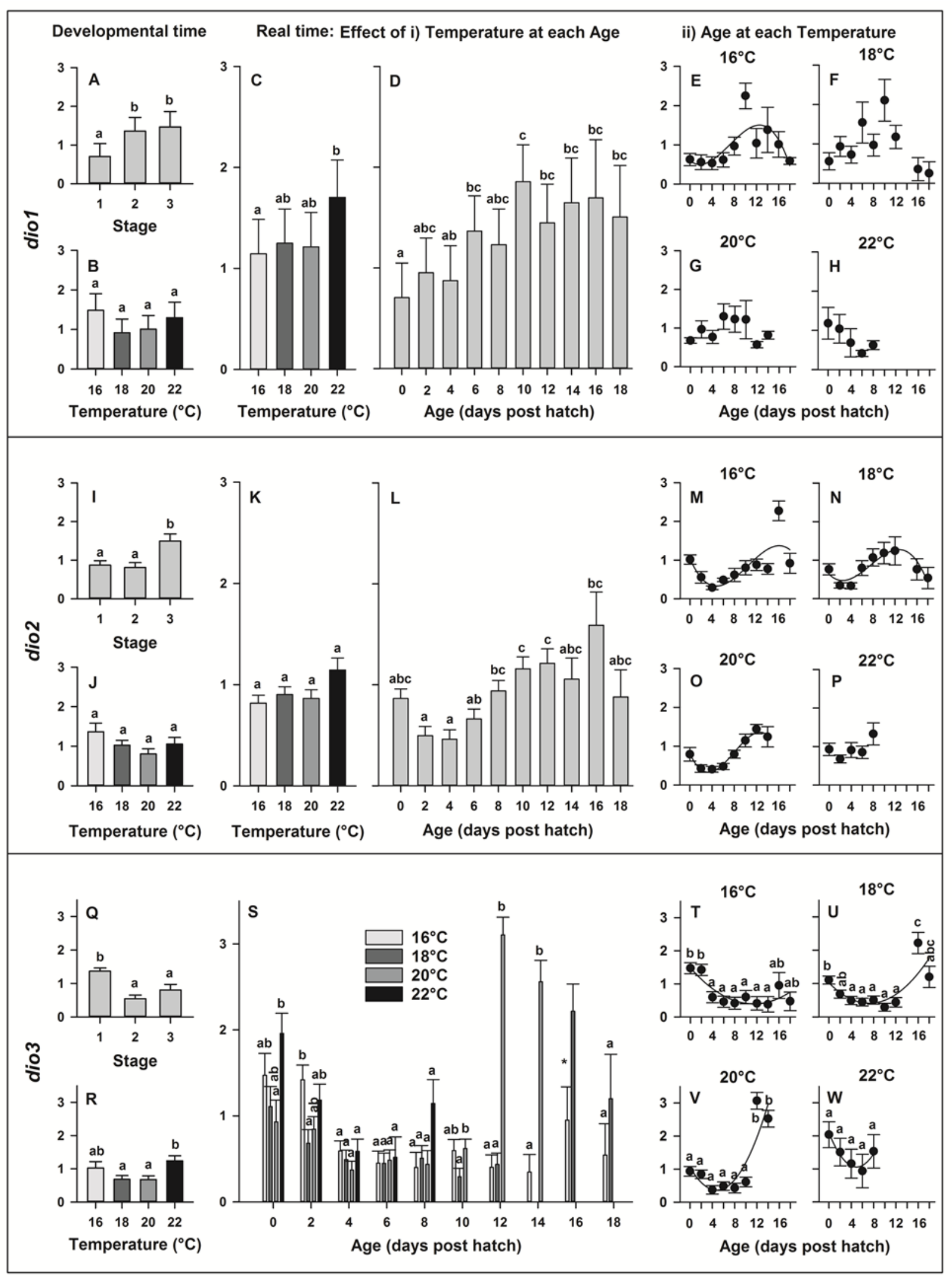

Figure_3 


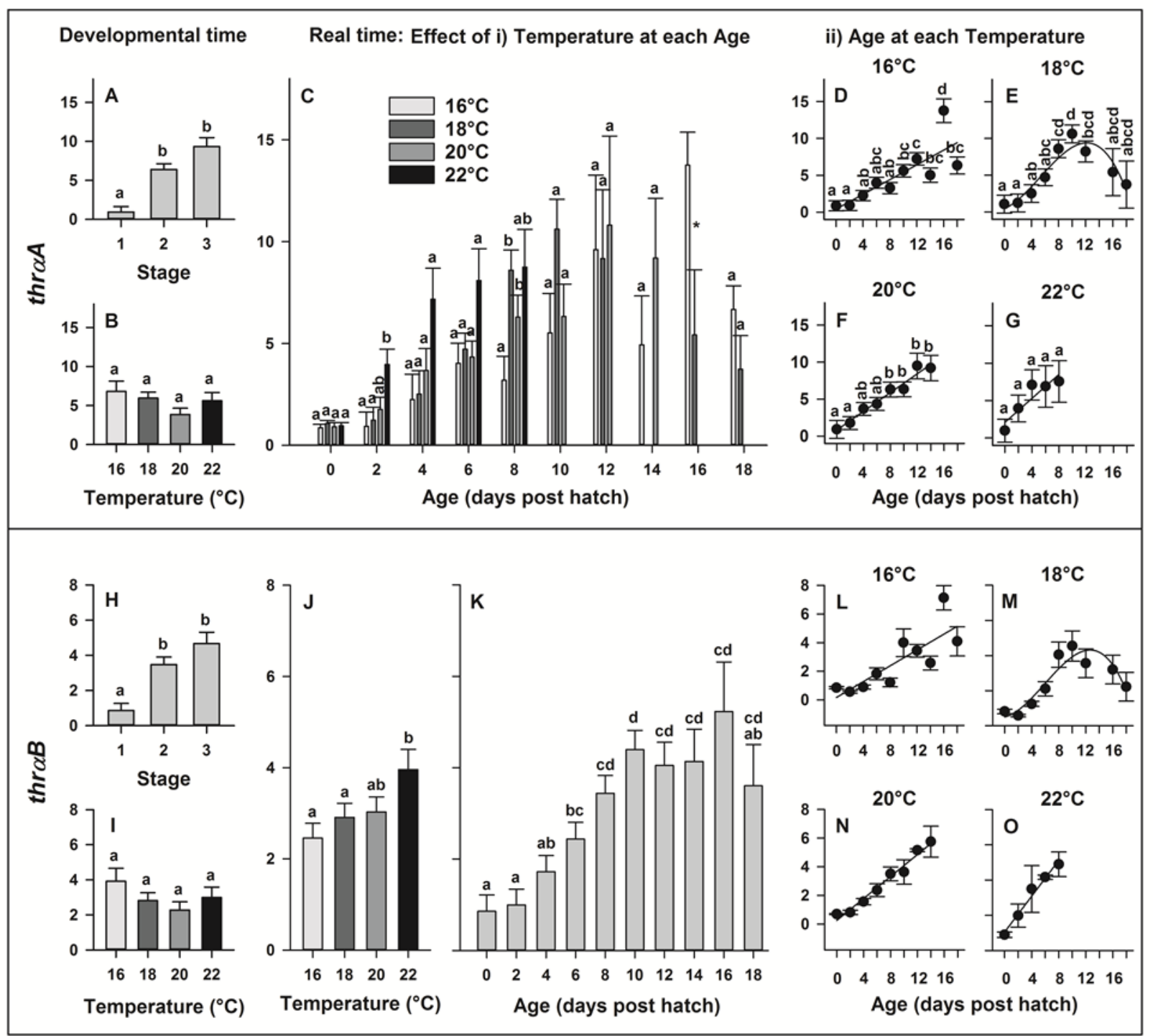

Figure_4 


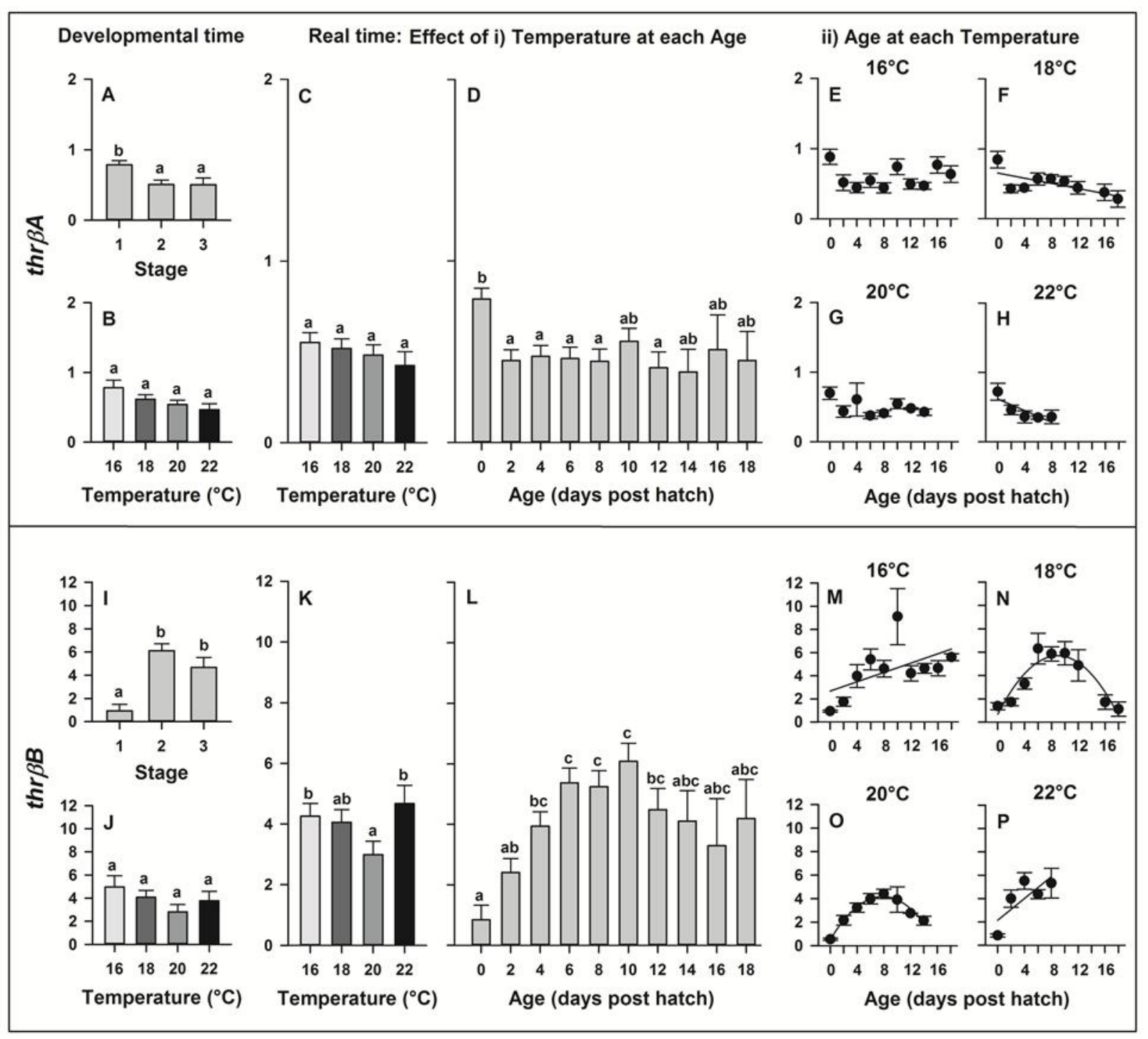

Figure_5 